\title{
A trajetória das atletas de basquete no Brasil: Um estudo com a Liga de Basquete Feminino.
}

\author{
Guilherme de Souza Watoniki, Cesar Vieira Marques Filho, Larissa Rafaela Galatti.
}

\section{Resumo}

O basquete feminino brasileiro sofreu um declínio tanto nos resultados internacionais quanto no número de praticantes. Com vistas à melhoria deste panorama, foi criada a Liga de Basquete Feminino, em 2010. Neste estudo, realizamos o mapeamento do perfil e trajetória das atletas da Liga. Por meio de questionários respondidos por 57 atletas, foi possível conhecer como se deu o seu percurso nos âmbitos esportivo, econômico e sociocultural, bem como sua situação atual e planos para o pós-carreira.

Palavras-chave: Basquete, Atletas, Trajetória.

\section{Introdução}

O basquete é um esporte tradicionalmente praticado no Brasil, presente em escolas, espaços públicos, competições e federações (CANAN; SILVA, 2013; BENELI, 2018). Porém, ao abordar o basquete feminino nacional, percebemos que as conquistas mais expressivas ficaram em um passado cada vez mais distante, como o mundial em 1994, tido como o principal maior título (GALATTI et.al, 2015), e também as medalhas olímpicas de prata e bronze conquistadas em Atlanta, 1996, e Sidney, 2000, respectivamente (FIBA, 2018).O declínio da seleção contrasta com a situação da modalidade no país que, segundo Antonelli (2012), sofreu uma queda no número de praticantes em todas as idades. Neste cenário, surgiu a Liga de Basquete Feminina (LBF), em 2010, com o intuito de promover a reestruturação e valorização da modalidade.

Uma das medidas adotadas pela LBF foi uma parceria firmada com a UNICAMP, a fim de contribuir com o desenvolvimento da Liga a partir de fundamentação científica. Dentre as diferentes frentes de atuação, foram aplicados questionários com $X$ atletas atuantes na LBF. A partir dos dados coletados, foi possível mapear o perfil e trajetória destas atletas, conhecendo características do seu percurso nos âmbitos esportivo, econômico e sociocultural, bem como sua situação atual e planos para o pós-carreira.

\section{Resultados e Discussão}

Os resultados obtidos foram tratados e divididos em três categorias: contextos de prática, passagem pela seleção nacional e características socioeconômicas.

Quanto aos contextos de prática, observamos que a escola é o local onde as atletas tiveram seu primeiro contato com a modalidade, diferentemente do basquete masculino, onde a maioria dos atletas da NBB iniciaram no clube (CUNHA et al., 2017).

Analisando as passagens pelas seleções foi possível ver semelhança entre o basquete feminino e o masculino, pois a grande maioria dos atletas passou pelas seleções de base, porém poucos chegaram à seleção adulta (CUNHA et al., 2017). Estes dados podem indicar que as seleções de base são importantes para a formação de atletas de basquete, mas pouco eficazes para o desenvolvimento de jogadores para servir a seleção principal.

No âmbito das características socioeconômicas podemos destacar a igualdade na distribuição de auxílios entre as categorias de base e as atletas profissionais, diferentemente do que acontece no basquete masculino, especialmente em Minas Gerais, onde os jogadores de base possuem uma quantidade auxílios muito limitados se comparados com os profissionais (REIS et al., 2014). Este contexto demonstra certo interesse no desenvolvimento do basquete feminino nas categorias de base.

\section{Conclusões}

Conhecer o perfil e trajetória das atletas é de suma importância para entendermos quem são as protagonistas da modalidade e como a mesma está sendo estruturada. Estes dados podem colaborar com o diagnóstico de problemas e auxiliar a encontrar soluções acerca do basquete feminino no Brasil. Desta forma, o resultados obtidos tem grande potencial para contribuir com o desenvolvimento do basquete feminino brasileiro.

ANTONELLI, M.; GALATTI, L. R.; MACHADO, G. V.; PAES, R. R Pedagogia do esporte e basquetebol: considerações para a elaboração de programa esportivo a partir do clube divino salvador, Jundiaí. Conexões, Campinas, v. 10, n. 2, p. 49-65, maio/ago. 2012.

BENELI, L. M. Trajetória esportiva de atletas de alto rendimento no basquetebol masculino e feminino no Brasil: estudo retrospectivo. Tese (Doutorando em Educação Física) - Faculdade de Educação Física - Universidade Estadual de Campinas, 2018.

CANAN, F.; SILVA, R. V. Considerações histórico-sociológicas acerca do basquete de rua e suas possíveis relações com a educação física escolar. Caderno de Educação Física e Esporte, Marechal Cândido Rondon, v. 11, n. 1, p. 65-77, jan./jun. 2013.

CUNHA, L. D. ; FRAIHA, A. L. ; DARIDO, S. C.; PEREZ, B. L.; GALATTI, L. Perfil de los jugadores del Nuevo Baloncesto Brasil (NBB). Cuadernos de Psicologia del Deporte, v. 17, p. 119, 2017.

FIBA. INTERNATINAL BASKETBALL FEDERATION. Women's World Cup History. Disponível em: <http://www.fiba.basketball/womensbasketballworldcup/2018/womens-worldcup-history\#tab=element_2_5>. Acesso em: 20/06/2019.

GALATTI, L. R.; PAES, R. R.; MACHADO, G. V.; GONÇALVES, C. B.; SEOANE, A. M. Determinantes de excelência no basquetebol feminino: as conquistas da seleção Brasileira na perspectiva das atletas. Rev. Educ. Fís/UEM, Maringá, v. 26, n. 4, p. 621-632, 4. trim. 2015.

REIS, C., MORAES, L., FERREIRA, M., NOCE, F., \& COSTA, V. Recursos humanos, financeiros e materiais de atletas de basquetebol nas categorias de base e a percepção dos treinadores sobre a formação dos atletas . Revista Brasileira De Educação Física E Esporte, v. 28, n.3, p. 491-503, 2014. 